\title{
OSVRT NA GAZALIJEVE OPSERVACIJE O VRLINAMA UČENIKA I UČITELJA
}

\section{Sažetak}

Smatrajući korisnim i potrebnim materijalom za razmišljanje $u$ ovom radu će biti riječ o međusobnim odnosima zainteresovanih osoba na putu sticanja nauke. Osnovni likovi i pojmovi koji se mogu susresti na tom polju su učitelji - podrazumijevaju se sva zvanja osoba koje pružaju znanje - i učenici - sva lica koja primaju znanje. Treća važna karika koja ih međusobno povezuje je nauka.

Da bismo bili konkretniji, ovdje će biti riječ o međusobnim odlikama i vrlinama osoba koje se vezuju za nauku. Cilj nam iznijeti viđenje ove tematike očima jednog alima iz vremena procvata naučnih disciplina $u$ islamskom svijetu. Također, željeli bismo svojim komentarima ukazati na trajne vrijednosti u svim vremenima, i zbog čega je Gazalija „čitan“ $i$ „tumačen“ skoro čitav jedan milenij. Konkretnije rečeno, ove godine se obilježava devetstota (900) godišnjica od smrti ovog plodnog alima (umro 1111. godine).

U ovom radu dat je jedan osvrt na pedagoške metode koje je Gazalija kroz formu 'uvjeta za uspjeh' ponudio $i$ učenicima $i$ učiteljima (nastavnicima, profesorima i predavačima). Ono što veže učenike $i$ učitelje je nauka, odnosno spona koja ih moralno i naučno uzdiže. Gazalijevi savjeti učenicima su dati u deset tačaka, od kojih svaka ukazuje na svoju važnost $i$ bitnost. Bez primjene uvjeta koje je Gazali postavio, došao bi u pitanje $i$ sam uspjeh učenika, a ta upitnost bi pogotovo bila izražena u njenom prihvatanju kod Allaha, dž.š.

Među tim uvjetima koje on iznosi učeniku je i zahtjev da vodi računa o duhovnoj i tjelesnoj čistoći; da se ne uznosi iznad svog učitelja; da izbjegava besplodne rasprave; da zna šta mu je cilj $u$ izučavanju određenih nauka, itd.

U osam uvjeta za uspjeh učitelja, Gazali je na prvo mjesto stavio ljubaznost $i$ prisnost sa učenicima. Pored toga naveo je još $i$

\footnotetext{
${ }^{1}$ Islamski pedagoški fakultet u Bihaću
} 
potrebu za slijeđenjem uputstva Poslanika, s.a.v.s., te davanje korisnih savjeta $i$ skladnost riječi $i$ djela $u$ procesu učenja. Analizom Gazalijevih savjeta upućenih učenicima i učiteljima otkrit ćemo da one u sebi nose trajnu vrijednost, kao i to da je traženje Allahove blizine i zadovoljstva suština ljudskog života, pa tako i naukovanja.

Ključne riječi: Gazali, islam, nauka, uvjeti, učenik, učitelj, uspjeh u nauci, važnost nauke, korist i ciljevi nauke.

\section{UVOD}

Pred nama je analiza i komentar na ukupno osamnaest tačaka koje su podastrte u djelu Ihja' ulumid-din' ${ }^{2}$, poznatog autora ElGazalija.

Muhammed, s.a.v.s., je bio prvi učitelj svojim drugovima ashabima, a oni su bili raznovrsne starosne dobi. Islamska naučavanja su u startu pokazivala rezultate, koji su se kasnije od ashaba prenosili na tabiine, a od njih novim generacijama, pa sve do danas.

Oblici prenošenja naučnih disciplina su se mijenjali kroz vrijeme i prostor, ali neki suštinski elementi su ostajali isti - naročito oni koji su se odnosili na osobine učitelja i učenika. Tokom stoljeća se moglo pratiti kakve su bile metode i sredstva pri sticanju nauke, te kako su doživljavali velike preobražaje u kvalitativnom smislu. Međutim, ono što je moralo krasiti učenika i učitelja su trajne $i$ neprolazne vrijednosti u pogledu međusobnog poštivanja $i$ razumijevanja.

Jedno takvo razmišljanje, pretočeno i u pisanoj formi, dospjelo je i do nas, a riječ je o veoma zanimljivim opservacijama Ebu-Hamida el-Gazalija. ${ }^{3}$ Ovaj vrsni učenjak dotakao se ove tematike u svome djelu Ihjau ulumid-din - Preporod islamskih nauka, na takav način da bi vrijedilo dati osvrt na njega.

Kada su u pitanju uvjeti učenika za njegovo uspješno učenje Gazali izdvaja njih deset.

\footnotetext{
${ }^{2}$ Ebu-Hamid el-Gazali, Ihja' ulumid-din, Darul-ma'rife, Bejrut, 1982.

${ }^{3}$ El-Gazali (1053-1111) je jedan od najplodonosnijih islamskih spisatelja sa preko 700 djela.
} 
Prvi uvjet učenika koji želi postići uspjeh je obaveza učenika da vodi računa o duhovnoj čistoći. Govoreći o ovoj potrebi za učenika, Gazali navodi da je namaz (molitva) ibadet srca kojim se dolazi do blizine Uzvišenom Allahu. Svakako, prije kontakta s Gospodarom treba obaviti određene pripreme, a one se sadrže u duhovnoj i tjelesnoj čistoći.

Uzvišeni Allah u Kur'anu kaže: Zaista Allah voli one koji se duhovno i tjelesno čiste. ${ }^{4} \mathrm{~A}$, i mnogobrojni su hadisi koji upućuju na potrebu održavanja čistoće, od kojih se najčešće navodi: Allah je čist $i$ voli čistoću. ${ }^{5}$ Čistoća je nešto lijepo i u prirodi svakog ljudskog bića treba da zauzima jedno od glavnih mjesta.

U tom smislu Muhammed, s.a.v.s., kaže: Zaista je Allah lijep $i$ voli ljepotu ${ }^{6}$, a čistoća je, svakako, sastavni dio ljepote, kao što je i prljavština sastavni dio i oličenje nečega ružnog. Koliko li se, pak, mudrosti nalazi u slijedećim Poslanikovim, s.a.v.s., riječima, kada kaže: Ko mi garantuje čistoću onoga što mu je između vilica i onoga što mu je između nogu, ja mu garantujem mjesto u džennetu. ${ }^{7}$

Upozorenje koje je predočeno u ovom hadisu odnosi se na čiste spolne organe, koji neće činiti blud, kao i na čiste jezike, tj. usta kojima će se govoriti samo lijepe riječi, a neće biti zloupotrijebljeni da govore ružne riječi.

Zato osobe koje se žele baviti naukom, moraju imati i strahopoštovanje prema Stvoritelju koje će ga stalno podsjećati na obavezu čistoće u svakom pogledu.

Gazali u ovom djelu navodi i kur'anski ajet, gdje kaže Uzvišeni: Zaista, Allaha se boje od robova Njegovih - učeni. ${ }^{8}$ Da, istinski tragalac za naukom u sebi stalno nosi strah i ljubav prema Allahu, dž.š., Koji ga upozorava da ne uradi nešto što će ga ukaljati. Činjenica je, također, da ima učenika i lošeg ahlaka, a koji su uspjeli doći do zavidnog znanja. Ali, ne - takav nikada neće imati suštinsku spoznaju niti sreću na Ahiretu. Ibn-Mes'ud, r.a., kaže: Znanje nije samo obilno

\footnotetext{
${ }^{4}$ El-Bekare, 222.

${ }^{5}$ Ebu-Davud, Edeb, 41.

${ }^{6}$ Muslim, Iman, 147.

${ }^{7}$ Buhari, br. 6474.

${ }^{8}$ Kur'an, El-Fatir, 28.
} 
kazivanje - nego svjetlo koje vodi do srca. ${ }^{9}$ Zadovoljstvo u srcu i duši vodi učenika ka uspjehu, jer u protivnom dobijamo rezultat koji ukazuje na grubost i aroganciju.

Drugi uvjet za uspjeh učenika na polju nauke ogleda se u tome da što manje bude okupiran dunjalučkim potrebama. Po ovom pitanju Gazali preporučuje da se učenik 'oslobodi' svih drugih obaveza, te da se usmjeri isključivo na nauku. I danas smo svjedoci da imamo vrijednih učenika i studenata koji su, nažalost, prekinuli svoje obrazovanje u nedostatku neophodnih finansija. S druge strane, vidimo da i pojedine institucije stipendiranjem učenika i studenata žele olakšati njihovo obrazovanje. Sigurna materijalna situacija pruža priliku onima koji su željni nauke da se bave isključivo naukom i tada daju izvrsne rezultate. Nekada smo u prilici i da čujemo kako se pojedini studenti 'snalaze' na takav način da bilo šta rade, kao raznose poštu, novine, konobarišu, cijepaju drva, sakupljaju sekundarne sirovine ili obavljaju neke slične poslove boreći se sa materijalnom situacijom. Ali, u takvim poslovima gube dragocjeno vrijeme za učenje ili im školovanje 'duže' traje. Tako su i nastajali STUDENTSKI SERVISI koji, u nekim momentima, mogu odigrati svoju ulogu u funkciji pomoći studentima.

Gazali navodi primjer okupiranosti dunjalučkim potrebama $\mathrm{u}$ vrijeme sticanja nauke poredeći to sa vodom koja se razvodnjava, pa nešto zemlja upije, a nešto $\mathrm{i}$ ispari, a na koncu njiva ne bude u cjelosti napojena. Jer, ljudske misli odlutaju raznim kanalima i dunjalučkim obavezama, umjesto da su usmjerene ka učitelju i knjigama. Pretpostavljamo da je Gazi Husrev-beg znao za ovakva Gazalijeva promišljanja, te je osnivanjem Medrese u Sarajevu zavještao njenim učenicima besplatno školovanje, dodavši i džeparac. Na ovakav način učenicima je spao teret i briga za dunjalučkim potrebama, a ostala je glavna obaveza da se maksimalno predaju nauci. Nakon ovakvog odnosa se mogu očekivati pravi i potpuni uspjesi kod onih željnih nauke.

Treći uvjet za uspjeh učenika se nalazi u činjenici u kojoj se učenik ne smije tokom nastave uznositi iznad svoga učitelja i nauke kojom se bavi. Poslušnost kod učenika treba da bude kao poslušnost

${ }^{9}$ El-Gazali, Ihja ..., str.49. 
bolesnika prema ljekaru koji mu želi sve najbolje. ${ }^{10}$ Ukoliko se vratimo u vrijeme Gazalija, vidjet ćemo da su učenici birali učitelja, pa su ga, zbog toga, još više i poštivali.

Iako savremeni način obrazovanja preferira Bolonjski proces, njegova primjena po spomenutom pitanju još nije u potpunosti zaživjela. Naime, još uvijek se rijetko susrećemo da studenti koriste mogućnost ,prohodnosti“‘, pa da određene naučne discipline polažu na drugim fakultetima i pred drugim profesorima.

U svakom slučaju uznositi se iznad svoga učitelja ubraja se u domen oholosti i nepoštivanja.

U vrijeme kada je učitelj bio na poziciji istinskog autoriteta, bivalo je i slučajeva da otac neposlušnog učenika pozove njegovog učitelja na gozbu sebi. ${ }^{11}$ To bi bio znak da roditelj razumije uvođenje reda, pa makar u pitanju bilo i vlastito dijete. Iako je, kako kažu, 'štap iz Dženneta izveden', danas se on u procesu odgoja i obrazovanja ne upotrebljava, premda su još uvijek žive generacije onih koji pamte uvođenje reda i discipline strahom od batinanja i kazne štapom. Batine više nema u školama, učenici nemaju straha od toga, a onda nemaju straha ni od koga, iako im to ne daje za pravo da se uobraze i uzohole prema svojim učiteljima.

Učenik u svakom pogledu treba slušati i slijediti svoga učitelja, jer, ma koliko neke postavke učitelja bile neobične, to može biti razlog koji u tom trenutku učenik nije shvatio. Gazali kaže: Učiteljeva greška je bolja od učenikove ispravnosti. ${ }^{12}$

U Kur'anu imamo vrlo lijep primjer odnosa učitelja i učenika kroz kazivanje o Hidru i Musau, a.s.: Ti sigurno nećeš moći sa mnom da izdržiš, a i kako bi izdržao ono o čemu ništa ne znaš? ${ }^{13}$ Nakon ovih riječi upućenih Allahovom, dž.š., poslaniku Musau, a.s., Hidr zahtijeva šutnju, poslušnost i predanost, pa kaže: Ako ćeš me već pratiti - reče ovaj, onda me ni o čemu ne pitaj, dok ti ja o tome prvi ne

\footnotetext{
${ }^{10}$ El-Gazali, str. 50.

${ }^{11}$ Po kazivanju r. Hifzije Hasandedića, koji spominje da se takav slučaj desio u Blagaju kod Mostara

12 El-Gazali, str. 50.

${ }^{13}$ Kur'an, El-Kehf, 67-68.
} 
kažem. ${ }^{14}$ Ali, poznato je da se Musa, a.s., nije mogao strpiti, te je stalno postavljao pitanja koja su dovela do razlaza između njih dvojice.

Koliko je značajno gledati i slušati učitelja, kao i šutjeti prilikom sticanja nauke govori i jedna mudra priča u kojoj se kaže da je nekada davno jedan učenik završio svoje školovanje pred najvećim autoritetom u Istanbulu. Nakon toga je upitao svoga učitelja da li ima većih učenjaka od njega u svijetu. Osmjehnuvši se, učitelj mu je rekao da ima, te ako želi uputit će ga njemu. Učenik je prihvatio taj prijedlog, te mu učitelj napisa pismo i preporuku za jednu osobu koja je živjela u Semerkandu. Kada je učenik željan znanja došao u taj grad, raspitao se o osobi kojoj je trebao uručiti pismo. Tako je upućen na kraju grada kod jednog kovača, koji je, ustvari i bio tražena osoba veliki učitelj. Nakon čitanja pisma i razgovora $s$ iznenađenim učenikom, učitelj - kovač nudi učeniku da svojim rukama stišće mijeh s usmjerenim zrakom u vatru. Za to vrijeme ne smije ništa pitati, naprotiv, treba samo da gleda šta se dešava i da sluša šta i o čemu govori učitelj s mnogobrojnim mušterijama koje dolaze u kovačnicu. $\mathrm{Na}$ taj način učenik je shvatio vrijednost slušanja, te se za pet godina obogatio znanjem kojeg je ponio sa sobom u svoje krajeve gdje je i postao vrstan učitelj.

Gazali, također, upozorava učenika da prilikom sticanja znanja shvati kada je učitelj umoran i vodi računa da ga ne zamara. Ukoliko ima i nekih ličnih tajni kod učitelja, učenik ih ne smije otkrivati, niti istraživati učiteljeve previde i pogreške.

Četvrti uvjet za uspjeh učenika u traženju nauke jeste taj da učenik ne ulazi u polemike o razlikama i razilaženjima u nauci. To iz razloga što postoji mogućnost da svojom nezrelošću ošteti svoj um i razumijevanja kojih će se držati kasnije. Ovdje Gazali upozorava početnika da se ne upušta u rasprave, kao što ne bi bilo dobro ni da neko ko tek prihvati islam živi u društvu nevjernika. ${ }^{16}$ To dalje znači da za njega postoji realna opasnost po pitanju njegovih uvjerenja, a koja on treba jačati u društvu vjernika. Kada se osnaži iman (vjera) u

\footnotetext{
${ }^{14}$ Kur'an, El-Kehf, 70.

${ }^{15}$ Salih, Ibrišević: Tumačenje Mesnevije, Sarajevo, 1980. (usmena predaja)

${ }^{16}$ El-Gazali, str. 51.
} 
njegovom srcu, onda ne postoji bojazan da će mu se šta loše desiti u komunikaciji sa nevjernicima.

Prvi redovi borbe na bojnom polju su rezervisani za iskusne, hrabre i neustrašive, a tek poslije njih dolaze oni koji se kale i pomalo jačaju. U primjerima ovog četvrtog uvjeta Gazali navodi i kakav pogled mogu imati učenik i učitelj po pitanju onečišćenja vode. Tako, na primjer, ako bi ubacili u čašu vode nešto nečistoće, a duplo više takve nečistoće ubacili u more, rezultati nisu isti. Neuki neće shvatiti da će nečistoća nadvladati čistoću vode u čaši, ali će zato more eliminisati takvu nečistoću svojom ogromnom snagom i količinom.

Peti uvjet za uspjeh učenika leži u tome da on teži svestranom obrazovanju, kako bi savladao što više naučnih disciplina.

Gazali želi istaći ovdje faktor potrebe razumijevanja drugih nauka, jer postoji opasnost od nepoznatog, koja nekad prelazi i u averziju prema drugim naučnim disciplinama. U ovom polju navodi i riječi jednog pjesnika koji kaže da su bolesnim ustima i najslađe vode bljutave i neukusne. ${ }^{17}$ Ovdje bolesnik predstavlja neukog, a čiste i ukusne vode - vrle nauke.

$\mathrm{S}$ obzirom na to da ispravne nauke vode ka Onome Koji je Najznaniji, postoje i druge nauke čiji putevi ne vode ispravnom cilju. Dakako, upoznavanjem više disciplina u nauci samo se olakšava prava spoznaja, a u isto vrijeme i obogaćuje učenik.

Šesti uvjet za uspjeh učenika je jednim dijelom vezan za prethodni (peti) uvjet, jer upozorava učenika da ne bude vezan samo za jednu naučnu disciplinu, ali mu dužina životnog vijeka ne omogućava da izučava sve postojeće naučne discipline. Stoga će učenik voditi računa da izabere ono što mu je bitno u njegovom životu, za čime ima i afinitet i ono što realno može dosegnuti.

Gazali preporučuje da se od svih bitnih nauka uzme ono što je najbitnije. Svakako da je u podjeli svih tih raznih nauka prednost dao nauci od koje će čovjek imati najviše koristi, ali ne dunjalučke, nego ahiretske. Za njega nauka nema svrhe ako preko nje čovjek ne može doći do spoznaje o Bogu. Zato se tragaocu na putu znanja nude one

\footnotetext{
${ }^{17}$ El-Gazali, str. 52.
} 
discipline koje će ga duhovno osnažiti i obogatiti za ono vrijeme kada materijalne vrijednosti neće skoro ništa predstavljati.

U tom pogledu Gazali upozorava na potrebu učenika da svojim vlastitim trudom $i$ učenjem uroni $u$ more spoznaje čije se dno ne vidi, ${ }^{18}$ a ne da se pasivno oslanja samo na naslijeđene duhovne vrijednosti od svojih predaka. Da, upravo tako, i danas možemo čuti kako se neko hvali svojim precima - kako su oni bili učeni i poštovani - a ovi ništa ne čine da ih dostignu, pa i preteknu na tim poljima.

Dakle, svestranost u obrazovanju je preporuka koja ima za cilj da čovjeka dovede do Allahove, dž.š., blizine i zadovoljstva.

Sedmi uvjet za uspjeh učenika jeste upozorenje da ne raspravlja neku naučnu oblast, ukoliko nije ranije o tome stekao potrebno predznanje.

Kod pojedinih naučnika može doći do kolizije između riječi i djela, ali se zbog tog čina ne može pod upit staviti ta određena disciplina. To znači da se mora uzeti u obzir razdvajanje same naučne oblasti i onoga koji se njome bavi, jer se zna desiti da pogriješi čovjek, a nije greška u samom učenju. Ukoliko, naprimjer ljekar uspostavi pogrešnu dijagnozu ili terapiju u liječenju, ne možemo zbog toga kriviti čitavu jednu važnu disciplinu kao što je medicina.

$\mathrm{Na}$ ovaj način se učeniku daje do znanja da mora biti dobro oprezan i spreman prije nego se upusti u raspravu sa nekim iz date oblasti. Gazali navodi činjenicu da je čovjeku svojstveno i da pogriješi, jer nema te oblasti kojom svako i u potpunosti može ovladati.

Time se učeniku poručuje da su realno mogući i usponi i padovi, ali da za padove ne možemo okriviti drugoga. Jedna naša poslovica kaže: Ne hvataj se u kolo ako ne znaš igrati! Odnosno, prvo nauči, pa se tek onda koristi time što si naučio. Ova poslovica može biti primjer i za mnoge druge stvari, ali joj smisao u ovoj stavci u potpunosti odgovara.

Osmi uvjet za uspjeh učenika je prepoznati razloge i faktore zbog kojih se jedna određena naučna disciplina odlikuje od ostalih. U prepoznavanju takvih izuzetno vrijednih nauka treba spoznati dvije

${ }^{18}$ Ibid. 
stvari, a to su: prava plodotvornost i snaga argumenata. ${ }^{19}$ Gazali želi istaći vrijednost jedne nauke kroz plodove koje ona proizvodi, a koji će donijeti korist na oba svijeta.

I pored toga što matematika i medicina, kao dvije važne discipline uživaju velike časti među svim naukama, nauka o spoznaji suštine života i spoznaji Allaha, dž.š., kao Stvoritelja ima daleko značajnije mjesto. Kroz sve vrste nauke treba da se proteže nit vjere u Boga, a što će rezultirati uspješnošću nje same. Ispravna nauka će se u praksi dokazati kao takva i biti prihvatljiva onda kada se vidi da ona donosi korisne plodove za čovjeka.

Jedna arapska poslovica kaže: Nauka bez rada je kao stablo bez ploda. Zato treba prepoznavati plodove koje donose naučne discipline u svakom pogledu i koje vode čovjeka uspjehu i sreći na oba svijeta.

Deveti uvjet za uspjeh učenika na polju nauke je taj da naučna dostignuća i uspjehe on koristi kao sredstvo za dostizanje krajnjeg cilja - blizine Allahu, dž.š.

Ovdje Gazali upozorava tragaoca za naukom da vodi računa šta mu je proritetni cilj koji želi postići kroz tu nauku. Cilj njegovog znanja nikako ne bi trebao biti zbog želja za vlašću, bogatstvom, položajem i tome slično. ${ }^{20}$ Osnovni cilj njegove nauke treba da bude osjećaj blizine Onome Koji sve zna, a pozicije do kojih učenjak može doći su prolaznog karaktera. Pa, i kada se dobijaju ili gube pozicije (vlasti i položaj) - pozicija kod Uzvišenog Allaha se neće gubiti.

U Kur'anu, a.š., se kaže: Allah će na visoke stepene uzdignuti one među vama koji vjeruju $i$ kojima je dato znanje. ${ }^{21} \mathrm{I}$, također se kaže: Oni su u Allaha po stepenima. ${ }^{22}$

Pozicije do kojih ljudi mogu doći su raznovrsne, shodno afinitetu, želji i trudu kroz nauku, a Allah je Taj Koji će svakome odrediti mjesto i položaj. Kroz Allahovo obećanje o nagradi učenjacima, nema mjesta za zabrinutost - niko neće biti oštećen za trud koji uloži na putu nauke.

\footnotetext{
${ }^{19}$ El-Gazali, navedeno djelo, str. 53.

${ }^{20}$ Ibid.

${ }^{21}$ Kur'an, El-Mudžadele, 11

${ }^{22}$ Kur'an, Ali-Imaran, 163.
} 
Deseti uvjet za uspjeh učenika na polju nauke se nalazi u razumijevanju duhovnih potreba. Naime, Gazali ovdje eksplicitno razdvaja nauke ovoga svijeta od nauka koje vode koristima na Ahiretu. U tom smislu on ukazuje na prolaznost života na ovome svijetu, te da treba davati prednost onosvjetskoj nauci. S obzirom na to da je duša vječna, kao dio Božijeg dara, treba putem duhovnih nauka iskazati svoju zahvalnost Gospodaru.

Ovosvjetske prolazne nauke treba izučavati i koristiti ih kao sredstvo (jahalicu) preko kojih se dolazi do pravih $\mathrm{i}$ vječnih vrijednosti. Medicina, kao i druge naučne discipline su veoma bitne i obaveza ih je izučavati, kako bi se time bilo od koristi ljudima. Svaka društveno korisna nauka ima svoje mjesto i ulogu, ali se ne smije zaboraviti potreba duhovne veze sa Bogom. Ta veza sa Stvoriteljem i vjera u Njega sprečava zloupotrebu nauke, jer pokvareni i učenik i učitelj mogu napraviti poteze kojima će naškoditi ljudima. U tom smislu je i mudra arapska poslovica koja kaže: Sačuvaj me, Bože, pobožnog džahila i pokvarena alima! Obje ove kombinacije ukazuju na negativne posljedice koje mogu biti proizvedene od pomenutih osoba.

U ukupnom promatranju Gazalijevih opservacija i metoda, nalazimo da su to savjeti tragaocima nauke kroz koje se protežu iskrene želje za uspjehom učenika.

\section{b) UVJETI ZA USPJEH UČITELJA U SVOM DJELOVANJU}

Pripremajući se za poziv učitelja, nastavnika ili profesora, čovjek svakako mora da prođe faze koje su prethodile dok je on bio učenik. Ukoliko je kao učenik bio pažljiv u sticanju nauke, bit će mu daleko lakše da pređe u fazu onoga koji drugoga podučava. Također, on je bio u prilici da primijeti sve ono što je pozitivno i što je vodilo uspjehu u radu njegovih učitelja.

Isto tako, postavši učiteljem, on će izbjeći sve ono što je smatrao eventualnim nedostacima u prethodnoj svojoj fazi. Bez obzira koliko se bavili naukom, odlike uspješnog učitelja moraju nositi trajne vrijednosti, čak i kroz protok vremena i promjene mjesta boravka i djelovanja. 
U tom pogledu Gazali u svom djelu Ihjau navodi osam uvjeta za uspješnost učitelja u misiji prenošenja znanja.

Prvi uvjet za uspjeh učitelja na polju širenja nauke se ogleda $u$ ljubaznosti i prisnosti sa učenicima. Kao podlogu za ovakav stav Gazali navodi hadis Muhammeda, s.a.v.s., u kojem kaže: Moj odnos prema vama je kao odnos roditelja prema svojoj djeci. ${ }^{23}$

Tokom svog odnosa prema drugima, pravi učitelj ima bojazan da zbog neke greške učenik ne dođe u opasnost, kao što roditelj čuva svoje dijete da ga vatra ne oprži. Briga učitelja nekada je veća i od roditeljske, jer se roditelji brinu da nahrane i obuku svoju djecu, dok kod učitelja dobivaju onu hranu duhovnog sadržaja kojom se puni srce i um.

Ukoliko bi učitelj upućivao isključivo na dunjalučke ciljeve, onda se ne bi puno razlikovao od roditelja. Zbog toga se on mora izdići iz okvira čisto materijalne prirode, zbog koje se može doći u opasnost sukobljavanja zbog materijalnih interesa. Opasnosti neće biti samo onda kada je svima cilj ahiretska nagrada i kada je uključena međusobna ljubav, a uklonjena mržnja i zavist. Kroz prisnost i ljubaznost s učenikom, učitelj daje do znanja učeniku da mu želi apsolutno dobro, te da će se ponositi uspjesima svojih učenika. Naravno, ako je pravilno usmjeren, učenik će uzvratiti još većim poštovanjem prema svome učitelju.

Zanimljiv slučaj se dogodio proteklog rata u našoj domovini. Naime, jedan profesor se žalio drugom kolegi kako sreće svog učenika koji se materijalno 'snalazi' u tim teškim vremenima, a na svog profesora ( $u$ isto vrijeme i susjeda) uopće se ne osvrće. Kolega mu odgovara: „Kako si ga to učio, pa te sada taj učenik i ne vidi!?“

Svakako da ima i svijetlih primjera gdje su učenici na mnogo načina znali uzvratiti ljubav i pažnju prema svojim učiteljima i profesorima dok god su oni živi.

Drugi uvjet za uspjeh učitelja leži u tome da tokom svoga rada sa učenicima obavezno slijedi Allahova Poslanika, s.a.v.s. Jedna od osnovnih odlika Muhammeda, s.a.v.s., prilikom prenošenja znanja je bila želja za blizinom Allahu, dž.š., i Njegovom zadovoljstvu.

${ }^{23}$ Ebu-Davud, Taharet, 4 i Nesai, Taharet, 35. 
Učitelju je čast i zadovoljstvo da tokom procesa naučavanja zajedno sa učenicima doživljava uspjehe onako kako je uspješan bio i Poslanik, s.a.v.s., sa svojim ashabima. Veoma važno je da učitelj ni jednim svojim potezom ne pokazuje niti zahtijeva od učenika platu. Za poslove upute i učenja koji vode ahiretskim koristima ne smije se tražiti dunjalučka nagrada.

Uzvišeni Allaha u Kur'anu traži od Svojih poslanika da ljudima kažu slijedeće: O narode moj! Za ovo ja od vas ne tražim blaga, Allah će me nagraditi! ${ }^{24}$ Materijalna dobra i kapital treba shvatiti samo kao sredstva koja su nužna samo da bi se prošlo ovim dunjalučkim životom.

Kada govorimo o odnosima učenika i učitelja u ovoj tematskoj jedinici prisjetimo se i profesora koji uslovljavaju studente kupovinom njihovih knjiga. Iako se to smatra kršenjem etičkog kodeksa i dalje se može čuti da na nekim fakultetima i univerzitetima takvo nešto još postoji. Osim toga postojale su (možda i još postoje) i gore situacije kao što su kupovine prolaznih ocjena kod 'strogih' profesora. Nekada se za jednog profesora matematike u Mostaru javno govorilo da slabi učenici srednjoškolci mogu proći ako plate stotinu njemačkih maraka, na kojoj je slika orla. Poznati slogan profesora, zbog tog orla, glasio je: „Tica-dvica.“

Nadamo se da su takva vremena iza nas i da sada u procesu obrazovanja brzo i efikasno djeluje eliminacija tako nesavjesnih učitelja - profesora.

Treći uvjet za uspjeh u radu učitelja se nalazi u tome da učeniku ponudi koristan savjet ili mišljenje. ${ }^{25}$ Tako se može desiti da učitelj upozori učenika na opasnost koja ga može zadesiti ukoliko učini određeni potez. A jedan od najbitnijih savjeta je, na primjer, da se ne prihvata određenog položaja ili pozicije za koju nije osposobljen i pripremljen.

Lahkomislenost ovoga svijeta i šejtansko došaptavanje učine da čovjek objeručke prihvati rukovodeću ulogu u društvu, a za koju nije spreman. Imamo primjera i onih kojima se ne nudi određena funkcija, a oni se sami 'guraju' i bore za nju. Tako Gazali uspoređuje ambicije

\footnotetext{
${ }^{24}$ Kur'an, Hud, 20.

${ }^{25}$ El-Gazali, navedeno djelo, 56.
} 
ljudi s polnim nagonom koji je prirodno, od Allaha, usađen. Takve ambicije mogu biti usađene u čovjeku da daje sve od sebe kako bi nešto naučio i saznao, da bi onda to znanje na druge prenosio. Allahov Poslanik, s.a.v.s., je upozoravao na činjenicu da ima i onih koji se bave naukom samo zato kako bi druge ponizili, ili govorili drugima kako neki pojedinci ništa ne znaju.

Savjeti i mišljenja učitelja su trajno dobro, plod dugotrajnog iskustva, tako da učenik ne treba samo čekati kada će doći kakav savjet, nego ga i sam nekada potražiti. Bez potrebe da se dublje ulazi u analizu, ovdje možemo navesti i dio hadisa u kojem Muhammed, s.a.v.s., kaže: Vjera je savjet ${ }^{26}$ - kao potvrdu važnosti savjetovanja.

Četvrti uvjet za uspjeh učitelja je da on ima veoma razgrađen metod kojim će ukazivati na greške učenika. ${ }^{27}$ Učitelj svakako treba da vodi računa da učenik ne pogriješi. Međutim, pošto se to ipak dešava, onda učitelj mora biti veoma vješt u načinu i metodi ukazivanja na pogreške. Zbog opasnosti da još više ne pogriješi, učiteljevo ukazivanje treba da nekada bude $\mathrm{u}$ formi aluzije ili diskrecije, a nikako sa vikom i galamom. Kod tih momenata treba strogo voditi računa da se ne povrijedi ljudsko dostojanstvo i učenikova ličnost.

Vrlo bitno je i to da učitelj shvati učenikovu pogrešku, gdje neke vrste kažnjavanja treba da zamijeni lijepim savjetom. Razumnom biću treba prići s (pre)odgojnim metodama, jer se životinjama pristupa metodom dresure, kao što se, na primjer dešava u cirkusu sa konjima, lavovima, itd. To bi jednostavnije rečeno bilo: 'Dijete se odgaja, a životinja dresira.'

Praviti preveliki spisak zabrana učeniku od strane učitelja nekada vodi ka suprotnom efektu, jer je tako veća i opasnost da zapadne u grešku. S tim u vezi, lijepo bi bilo sastavljati manji spisak zabrana, a u isto vrijeme ponuditi mu daleko veći broj onoga što je korisno i dozvoljeno. Najbolji primjer za to imamo u zabrani alkohola, kada nam Uzvišeni Allah, kao alternativu, daje veoma veliki broj ugodnih sokova i drugih pića koja su ukusna, dozvoljena i ne opijaju.

\footnotetext{
${ }^{26}$ Buhari, Iman, 42

${ }^{27}$ El-Gazali, 57.
} 
Dakle, kada učenik pogriješi, učitelj će donijeti razumnu mjeru i povući potez koji neće učenika odvesti u još veći grijeh. Za h. Omera, r.a., se kaže kako je, kao halifa, dao da se određena osoba - pijanica protjera, kao vid kazne, a onda je ta ista osoba pribjegla kršćanima i prihvatila njihovu vjeru. Nakon toga je halifa rekao da više nikada neće donijeti takvu odluku. ${ }^{28}$

Razumni će, svakako, izvući pouku iz ovakvih primjera, kako se kasnije ne bi pravdali da nisu znali kako bi postupili u takvim situacijama. Svoje 'obrazovanje' možemo nadopunjavati i primjerima iz tuđih iskustava, ne čekajući da se to baš nama treba dogoditi, pa da bi ga znali riješiti.

Peti uvjet za uspjeh učitelja u svojoj misiji je da skrene učeniku pažnju da i druge nauke imaju svoju vrijednost i ne treba ih potcjenjivati. Jasno je da imaju i da postoje veliki broj različitih naučnih disciplina $\mathrm{i}$ da je skoro nemoguće biti vrstan u svemu. Ona oblast koja zaokuplja pažnju učitelja i učenika i jeste prioritet, ali to ne znači da smijemo drugog čovjeka ili druge korisne naučne discipline omalovažavati. Sve one imaju svoje mjesto i ulogu u društvu, ma koliko mi to smatrali 'lahkom' ili 'teškom' naučnom oblašću.

Zbog toga će pravi učitelj, bez imalo ljubomore, svojim učenicima sugerisati da upoznaju i drugačije oblasti, čime će se učenik još više obogatiti u znanstvenom pogledu. Jedna naša poslovica kaže: „Koliko jezika znaš, toliko ljudi vrijediš“", a to se odnosi samo na jezike i njihovu vrijednost, dok je, naravno, neprocjenjiva vrijednost onoga koji posjeduje znanje iz više naučnih oblasti ili zanata. Uzvišeni Allah u Kur'anu, a.š., kaže: Reci: 'Zar su isti oni koji znaju i oni koji ne znaju? 29

Šesti uvjet učitelju jeste da vodi računa o sposobnostima i mogućnostima samog učenika ${ }^{30}$, što prvenstveno znači da od njega ne zahtijeva ono što učenik nije u stanju shvatiti ili dokučiti. Za ovakav stav Gazali se poziva na riječi Allahova Poslanika, s.a.v.s., kada kaže: ...da se u komunikaciji sa ljudima spustimo na njihov nivo. ${ }^{31}$

\footnotetext{
${ }^{28}$ Nesai, Sunenun-Nesai, 8/319.

${ }^{29}$ Kur'an, Ez-Zumer, 9

${ }^{30}$ El-Gazali, 57

${ }^{31}$ Ebu Davud, Edeb, 20. i Nevevi: Rijadus-salihin, hadis br.355.
} 
Razumijevajući vrijeme u kojem je živio naš Poslanik, s.a.v.s., kao i vrijeme Gazalije koji se poslužio ovim hadisom (više vjekova iza Poslanika, s.a.v.s.), te vrijeme u kojem sada živimo - vidjet ćemo da su spomenute riječi univerzalna pouka učiteljima za sva vremena. Ljudski umovi nisu stvoreni niti izgrađeni po principu kalupa, pa da svi izgledaju i djeluju jednako. Stvoritelj ljudskog roda je postavio i zakonitosti koje se odvijaju oko čovjeka i u njemu samome, ali je oslobodio odgovornosti neke izuzetne slučajeve, kao i opterećenja iznad ljudskih mogućnosti. ${ }^{32}$

Učitelj treba da prepozna nivo svijesti učenika, pa ukoliko ustanovi određene nemogućnosti u razumijevanju kod istoga, neće mu se ni obraćati nekim neprepoznatljivim i velikoumnim riječima, jer bi to izgledalo kao prosipanje bisera po blatu.

Jasno je i da profesor može biti provociran provokativnim i nesuvislim pitanjima, tako da mora uvijek biti mudar i znati procijeniti kako i da li uopće odgovoriti na takva pitanja. Allah, dž.š. kaže:... A kada im se džahili obraćaju, oni im samo selam nazovu. ${ }^{33}$

Kur'an nas, na primjer, uči kako postupati sa imetkom onih osoba koji su rasipnici (rasturaju i ne vode brigu o imetku), pa kaže: $I$ rasipnicima imetke, koje vam je Allah povjerio na upravljanje, ne uručujte. ${ }^{34} \mathrm{~S}$ obzirom na to da je $\mathrm{u}$ interesu rasipnika, za njihovu budućnost i bolja vremena, da im se ne dopušta rasipanje, isto tako je $\mathrm{i}$ znanje bogatstvo koje se ne bi trebalo baš svakome davati ili poklanjati - upravo iz te bojazni da ne dođe do njegove propasti i zloupotrebe.

U sklopu razumijevanja ovog uvjeta kod učitelja, u školama su uspostavljeni razredi i nivoi, tako da se učenicima nižih razreda ne daju materijali i zadaće kojima se bave učenici starijih razreda. Tek kada odrastu i dosegnu nivo njihovog mogućeg razumijevanja određene naučne građe, onda im se ta građa i dostavlja.

Sedmi uvjet za uspjeh učitelja je njegova sposobnost da pronađe adekvatno znanje i oblasti za one učenike koji nisu u stanju pratiti 'više' naučne nivoe. Zvuči veoma interesantno, ali kao da je

\footnotetext{
${ }^{32}$ Kur'an, El-Bekara, 286.

${ }^{33}$ Kur'an, El- Furkan, 63.

${ }^{34}$ Kur'an, En-Nisa', 5.
} 
Gazali ovdje dotakao nešto što je danas kod nas i u svijetu aktualizirano, a to je inkluzija. Kako pomoći i raditi sa djecom usporenog psihomotornog razvoja, je vrlo često pitanje i tema među današnjim pedagoškim uposlenicima?!

Takvim osobama treba pružiti osnovnu pomoć, a to je da se prvo osjećaju sastavnim dijelom društvene zajednice, a onda ih ne opterećivati iznad njihovih intelektualnih mogućnosti. Po Gazaliji ${ }^{35}$ njih ne bi trebalo uključivati u neke naučne debate koje se prepuštaju obrazovanijim i inteligentnijim osobama. Sami smo svjedoci da $u$ savremenom svijetu komunikacije danas imamo mogućnosti da putem raznih vrsta medija pratimo izjave ili razgovore sa osobama slabijeg intelekta. Nažalost, ima i ismijavanja na njihov račun, što je za svaku osudu jer društvo treba sprečavati sve vrste takvog etiketiranja.

Osmi uvjet za uspjeh učitelja na polju nauke je u tome da mu riječi i djela budu u potpunom skladu, jer takvi su samo istinski učitelji. Svojim okom i ostalim čulima učenik prati šta mu učitelj govori, a isto tako on veoma podrobno prati i kako se učitelj ponaša.

Svakako da postoji bojazan za uspjeh učiteljske misije, ako on upozorava na štetnost određenog postupka, a sam ga čini. Na primjer, ako učitelj govori o zabrani duhana ili njegovoj štetnosti, a sam ga koristi, onda pravi zabune u glavama učenika od kojih su dvije veoma bitne:

Prva je da učitelj nedovoljno poznaje materiju o kojoj izlaže svoje znanje.

Druga je stav i mišljenje koje se formira u glavama učenika, a to je da možda njihov učitelj ne govori istinu. U oba slučaja rezultat će pokazati neuspjeh učitelja.

Kao siguran i čvrst argument ovom uvjetu, Gazali ${ }^{36}$ navodi kur'anski ajet: Zar da od drugih tražite da dobra djela čine, a da pri tome samo sebe zaboravljate! ${ }^{37}$ Greške koje mogu počiniti učitelji donose daleko veće posljedice, nego kada bi takve iste greške činile neznalice i oni koji su na njihovom nivou. Zbog toga što bi nekada

\footnotetext{
${ }^{35}$ El-Gazali, navedeno djelo, str. 58

${ }^{36}$ Ibid.

${ }^{37}$ Kur'an, El-Bekare, 44.
} 
neuki postupali onako kako vide učitelja da radi, bez da ih pitaju je li to $i$ to ispravno ili nije. S druge strane, vrstan učitelj puno toga može 'reći' svojim lijepim ponašanjem, nekada i bez potrebe da se izražava riječima.

\section{ZAKLJUČAK}

Živeći u eri naučne i tehnološke ekspanzije, ne možemo da se ne osvrnemo i na nauke od bitnih elemenata $u$ tom procesu. U prethodnom tekstu smo pokušali kraćim osvrtom ukazati na neke moralne vrijednosti koje su trajnog karaktera. Bez obzira na to što su za analizu uzeta razmišljanja i stavovi islamskog učenjaka od blizu jednog milenija ranije, etička vrijednost ovakvog mislioca ne zastarijeva.

Uvijek će biti učenika i učitelja, kao i njihovih međusobnih odnosa koji mogu biti svakakve prirode. Ukoliko smo razumjeli stepen poštivanja učenika prema učitelju, vidjet ćemo da je to nekad i $\mathrm{u}$ nekoj mjeri snažnije poštovanje i od samih roditelja. Nažalost u vremenu u kojem živimo možemo čuti kako pojedini učenici nasrću na svoje učitelje što je za svaku osudu. Još gore je kada čujemo da ima i takvih učenika koji su spremni čak i lišiti života svoje učitelje ili svoje kolege.

U rezultate koji bi se mogli donijeti u ovom zaključku svakako mogli bismo ubrojiti sljedeće:

- Moral i etika su jedne od neophodnih i temeljnih potreba na putu sticanja nauke.

- Učitelj (profesor, predavač) pored znanja treba biti ukrašen i svim osobinama dostojnim poziva kojim se bavi.

- Učenik (primalac znanja) mora uvijek biti svjestan svoje pozicije u odnosu na položaj svoga učitelja.

- Mogućnost vlastitog preispitivanja i učitelja i učenika da sami ,vide“" svoju realnu poziciju i da li bi kod sebe trebali nešto mijenjati.

- Učitelj je na nivou roditelja koji svome djetetu želi sve najbolje, a zauzvrat učenik iskazuje punu ljubav i pažnju u 
ophođenju sa učiteljem, na koga neće čak ni povisiti ton, a kamoli učiniti teži prekršaj prema njemu.

Bez primjera univerzalnih islamskih i ljudskih vrijednosti, nema ni uspjeha ni kod jednih ni kod drugih, što se dalo vidjeti iz priloženog osvrta.

\section{Literatura:}

1. Kur'an, a.š., prijevod Besima Korkuta

2. Buhari, Sahihul-Buhari, prijevod Visoki saudijski komitet, Sarajevo 2009.

3. Ebu-Davud, Sunen Ebu-Davud, Darul-hadis, Kairo, 1988.

4. Gazali, Ebu-Hamid, Ihja' ulumid-din, Darul-ma'rif, Bejrut, 1982.

5. Muslim, Sahihu Muslim, Darul-Fijha, Damask, bez god. izdanja

6. Nesai, Sunenun-Nesai, Darur-Rejjan, Kairo, bez god. izdanja

7. Nevevi, Rijadus-salihin, Darul-'ilm, Bejrut, 1970. 
Izet Terzić,

\section{REVIEW OF GHAZZALI'S OBSERVATIONS ON THE VIRTUES OF STUDENTS AND TEACHERS}

\section{SUMMARY}

Considering this topic to be a useful and necessary material for thought, we shall in this paper address the mutual relations of people in the way of the acquisition of science. The main characters and concepts that may be encountered in this field are teachers, under which term we include all the persons with the knowledge - and students, which includes all persons who receive knowledge. The third important link that connects them is science.

To be more specific, we will talk about qualities and virtues of persons associated with the science. We aim to introduce these themes through the eyes of a scholar from the golden age of science in the Islamic world. Also, we would like to point out the lasting values from this period, and why is al-Ghazzali, "read" and "interpreted" for almost an entire millennium. More specifically, this year marks the nine-hundred year (900) anniversary of the death of this prolific scholar (died 1111).

The paper gives an overview of the pedagogical methods that Ghazali wrote in the form of 'conditions for success' offered to both students and teachers (teachers, professors and lecturers). Science is what binds students and teachers and it is a link which lifts them morally and scientifically. Ghazzali's advice to students consists of ten counts, each of which indicates its importance and significance. Without applying the conditions that were set by the Ghazzali, the success of students would come into question, and this would especially be pronounced in its acceptance of Allah.

Among these conditions for the student is the importance of the spiritual and physical purity, being humble towards his teacher, avoiding sterile debates, knowledge of goals for studying certain sciences, etc.

Among the eight conditions which are vital for the success of teachers Ghazali put kindness and familiarity with the students in the first place. In addition, he also mentioned the need for following the 
instructions of the Prophet, peace be upon him, and giving helpful tips and harmony of words and actions in the learning process. Through the analysis of Ghazzali's advice given to students and teachers we will discover that they carry within them a permanent value, and that seeking Allah's nearness and pleasure is the essence of human life, including apprenticeship.

Key words: Ghazzali, Islam, science, conditions, student, teacher, scientific success, importance of science, value and purpose of science 


$$
\text { الدكتور المساعد عزت ترزيتش }
$$

الالتفات إلى ملاحظات الغزالي عن فضيائل التلميذ والمعلم

\section{خلاصة البحث}

بناء على الاعتقاد بفائدة هذه المادة وأهميتها للتفكير فيها، فإن هذا البحث

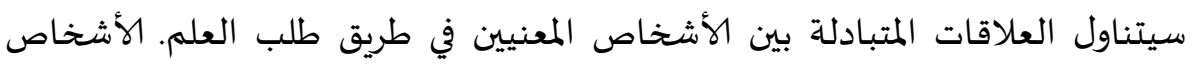

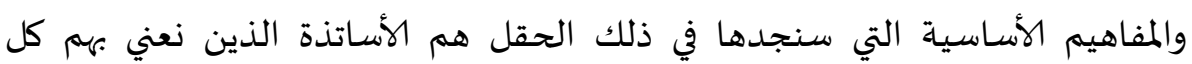

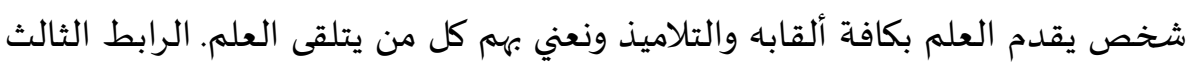
المهم الذي يربط فيما بينهم هو العلم.

إذا أردنا عرض ذلك بشكل أكثر تحديداً فإننا سنتكلم هنا عن الفضيائل والمزايا المتبادلة التي ترتبط بالعلم. هدفنا هو عرض هذه المادة بعيون أحد العلماء أيام ازدهار

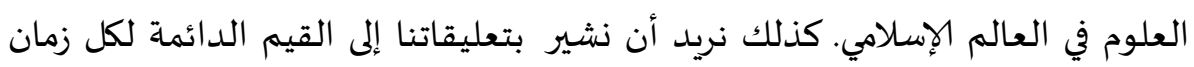

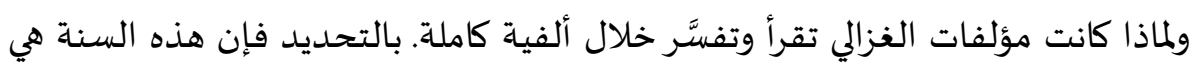

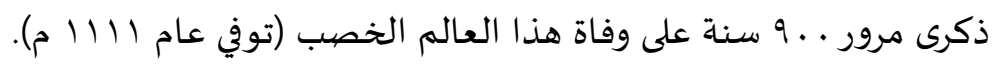

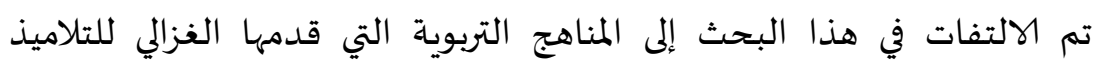

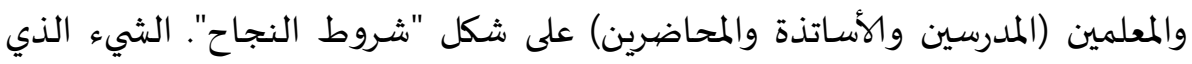

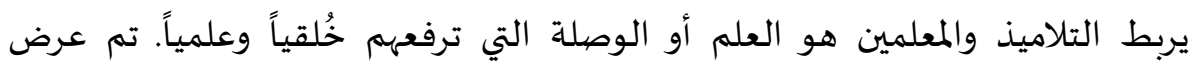
نصائح الغزالي للتلاميذ في عشر نقاط وكل واحدة منها تبين أهميتها. يتوقف نجاح المعاح التلميذ على تحقيق الشروط التي وضعها الغزالي وهذا التوقف يتجلى في قبول الله سبحانه وتعالى لله.

ضمن تلك الشروط التي يعرضها الغزالي للتلميذ هو طلب العناية بالنظافة

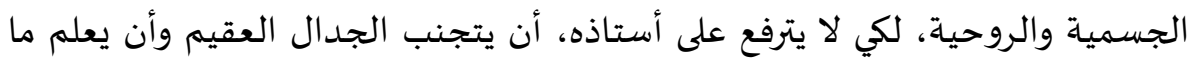
هدفه من دراسة بعض العلوم، إلخ.

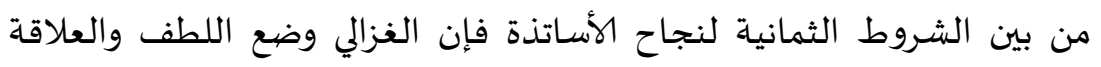

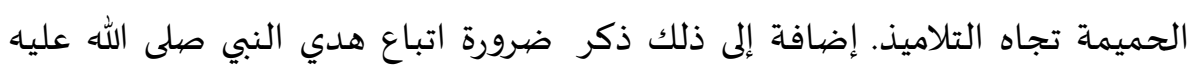

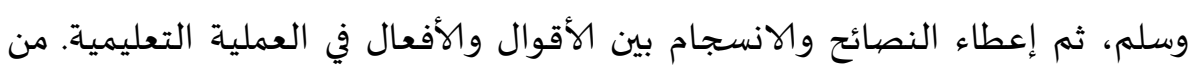


خلال تحليل لنصائح الغزالي الموجهة إلى التلاميذ والأسـاتذة سنكشف أهها تحمل القيمة الدائمة، وأن طلب القرب من الله ورضياه هما كنه الحياة الإنسـانية، وكذلك التعلم.

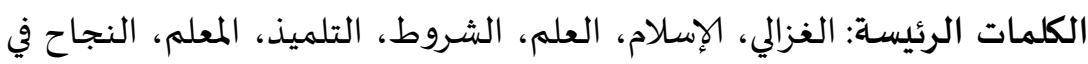

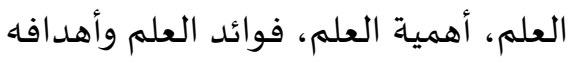

